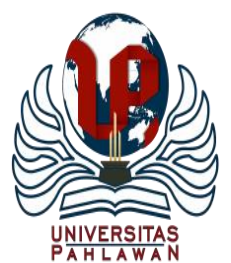

Edukatif : Jurnal Ilmu Pendidikan Volume 3 Nomor 4 Tahun 2021 Halm 1638 - 1646

EDUKATIF: JURNAL ILMU PENDIDIKAN

Research \& Learning in Education

https://edukatif.org/index.php/edukatif/index

\title{
Analisis Tingkat Minat Belajar Mahasiswa Pendidikan Ekonomi dalam Perkuliahan Daring Masa Pandemi Covid-19
}

\author{
Dessyta Gumanti ${ }^{1 凶}$, Serli Diovani Teza ${ }^{2}$ \\ Program Studi Pendidikan Ekonomi, Universitas Ekasakti Padang, Indonesia ${ }^{1,2}$ \\ E-mail : Dessytasays@gmail.com ${ }^{1}, \underline{\text { Serlidiovani@gmail.com }}^{2}$
}

\begin{abstract}
Abstrak
Penelitian ini bertujuan untuk mengetahui tingkat minat belajar mahasiswa pendidikan ekonomi Universitas Ekasakti dalam mengikuti perkuliahan daring selama masa pandemic Covid-19. Metode penelitian yang digunakan adalah deskriptif kualitatif dengan populasi sebanyak 33 orang yang terdiri dari mahasiswa semester 4 dan mahasiswa semester 6 . Teknik pengambilan sampel menggunakan total sampling sehingga jumlah sampel sebanyak 33 orang dengan teknik pengumpulan data menggunakan angket tertutup dan penyebaran angket menggunakan google form. Teknis analisis data menggunakan skala guttman. Hasil penelitian menunjukkan bahwa tingkat minat belajar mahasiswa pendidikan ekonomi Universitas Ekasakti dalam mengikuti perkuliahan daring sebesar 62,87\% (56-75\%) dengan kategori tingkat minat cukup baik. Tindak lanjut dari hasil penelitian ini diharapkan mahasiswa dapat meningkatkan partisipasi yang dapat menimbulkan rasa senang dan ketertarikan dalam perkuliahan daring selama masa pandemic sehingga tujuan pembelajaran dapat tercapai.
\end{abstract}

Kata kunci: pembelajaran daring, tingkat minat belajar, COVID-19.

\begin{abstract}
This study aims to determine the level of interest in studying economic education students at Ekasakti University in attending online lectures during the Covid-19 pandemic. he research method used is descriptive qualitative with a population of 33 people consisting of 4 th semester students and 6th semester students. The sampling technique used total sampling so that the number of samples was 33 people with data collection techniques using closed questionnaires and distributing questionnaires using google form. Technical data analysis using the guttman scale The results showed that the level of interest in studying economics education students at Ekasakti University in participating in online lectures was $62.87 \%$ (56-75\%) with a fairly good level of interest category. The follow-up to the results of this study is expected to increase student participation which can create a sense of pleasure and interest in online lectures during the pandemic so that learning objectives can be achieved.
\end{abstract}

Keywords: online learning, interest in learning, COVID-19.

Copyright (c) 2021 Dessyta Gumanti, Serli Diovani Teza

$\triangle$ Corresponding author

Email : Dessytasays@gmail.com

DOI : https://doi.org/10.31004/edukatif.v3i4.623

ISSN 2656-8063 (Media Cetak)

ISSN 2656-8071 (Media Online) 
1639 Analisis Tingkat Minat mahasiswa Pendidikn Ekonomi dalam Perkuliahan Daring Masa Pandemi Covid19-Dessyta Gumanti, Serli Diovani Teza

DOI : https://doi.org/10.31004/edukatif.v3i4.623

\section{PENDAHULUAN}

Memasuki tahun kedua wabah covid-19 masih belum usai melanda dunia termasuk Indonesia. Dampak wabah covid-19 masih sangat terasa terutama bidang pendidikan yang masih menerapkan pembelajaran jarak jauh (PJJ) atau sering disebut juga dengan pembelajaran online atau pembelajaran daring. Tidak hanya pendidikan tingkat sekolah, pendidikan tingkat tinggi seperti perkuliahan masih menerapkan pembelajaran daring untuk meminimalisir tingkat penularan Covid 19. Pembelajaran daring dapat dijadikan solusi pembelajaran jarak jauh ketika terjadi bencana alam. Seperti yang terjadi saat ini ketika pemerintah menetapkan kebijakan social distancing. Social distancing diterapkan oleh pemerintah dalam rangka membatasi interaksi manusia dan menghindarkan masyarakat dari kerumunan agar terhindar dari penyebaran virus COVID-19.

Aktivitas belajar dan pembelajaran telah berubah menyesuaikan dari proses pembelajaran tatap muka langsung dikelas (luring) menjadi pembelajaran online (daring). Hal ini sudah terlaksana semenjak adanya surat edaran Menteri Pendidikan dan Kebudayaan mengeluarkan Nomor 2 Tahun 2020 dan Nomor 3 tahun 2020 tentang pembelajaran secara daring dan bekerja dari rumah dalam rangka pencegahan penyebaran Corona Virus Disease (COVID-19). Berkaitan dengan edaran tersebut maka sejak 16 maret 2020 maka kegiatan pembelajaran mulai belajar dari rumah dan tidak perlu datang ke sekolah. (Argaheni, 2020). Begitu juga dengan pendidikan tinggi juga mulai belajar dari rumah menyesuaikan dengan edaran tersebut.

(Akhirman, 2021) menyebutkan bahwa Kuliah dengan system online bertujuan memberikan kesempatan kepada seluruh warga Negara Indonesia untuk dapat menikmati proses pembelajaran dimana saja berada. Kuliah daring sendiri dapat di pahami sebagai pendidikan formal yang diselenggarakan oleh perguruan tinggi yang peserta didiknya dan instrukturnya (dosen) berada di lokasi terpisah sehingga memerlukan sistem telekomunikasi interaktif untuk menghubungkan keduanya dan berbagai sumber daya yang diperlukan didalamya. Setiap mata kuliah/pelajaran menyediakan materi dalam bentuk rekaman video atau slideshow, dengan tugas-tugas mingguan yang harus dikerjakan dengan batas waktu pengerjaan yang telah ditentukan dan beragam sistem penilaian (Bilfaqi dalam Sutriyani, 2020).

Pembelajaran daring merupakan pembelajaran "dalam jaringan" sebagai terjemahan dari istilah online yang bermakna tersambung ke dalam jaringan komputer pembelajaran daring (online) sebagai strategi pembelajaran yang menyenangkan bagi pebelajar (mahasiswa) karena dapat menyimaknya dengan melalui smartphone, laptop, maupun komputer bukan hanya sekedar menyimak buku. Pembelajaran daring memiliki beberapa manfaat, di antaranya dapat (1) meningkatkan kadar interaksi pembelajaran antara mahasiswa dengan dosen, (2) memungkinkan terjadinya interaksi pembelajaran dimana dan kapan saja, (3) menjangkau mahasiswa dalam cakupan yang luas, dan (4) mempermudah penyempurnaan dan penyimpanan materi pembelajaran. Aktivitas belajar mahasiswa dengan pembelajaran daring (online) dapat membuat mahasiswa tidak merasa bosan, semakin tertarik, dan aktif dalam mengikuti pembelajaran, (5) Kebermaknaan belajar, kemudahan mengakses, dan peningkatan hasil belajar.

Walaupun sebenarnya dalam pendidikan tinggi, pembelajaran daring (online) atau sering juga disebut dengan e-learning bukanlah sesuatu yang baru dalam kegiatan pembelajaran. Dimana dalam tingkat pendidikan tinggi sebelumnya sudah mulai menerapkan Blended Learning yang menggabungkan antara perkuliahan tatap muka langsung dan daring. Konsep pembelajaran ini merupakan pembelajaran yang didesain dengan menggabungkan pembelajaran secara offline dan online. Pembelajaran Blended Learning yaitu campuran dari model tatap muka dan e-learning (Handayani, Annisya' and Andy, 2020). Dengan terjadinya pandemic covid-19 menyebabkan pembelajaran total untuk pembelajaran daring. Walaupun bukan sesuatu yang baru yang dihadapi mahasiswa terkait dengan pembelajaran daring, namun masih banyak ditemui kendala dalam penerapannya, bahkan cenderung membuat mahasiswa kurang berminat untuk mengikuti perkuliahan daring. 
1640 Analisis Tingkat Minat mahasiswa Pendidikn Ekonomi dalam Perkuliahan Daring Masa Pandemi Covid-

19-Dessyta Gumanti, Serli Diovani Teza

DOI : https://doi.org/10.31004/edukatif.v3i4.623

Minat belajar merupakan faktor yang sangat berpengaruh dalam proses pembelajaran. Minat besar sekali pengaruhnya terhadap kegiatan seseorang, sebab dengan minat akan melakukan sesuatu yang diminatinya dan sebaliknya tanpa minat seseorang tidak mungkin melakukan sesuatu (Harahap et al., 2021). Pembelajaran akan berhasil jika diiringi dengan minat belajar yang tinggi. Rasa ketertarikan dan senang akan belajar akan membantu menyukseskan kegiatan belajar mengajar.

Minat belajar merupakan suatu rasa untuk menyukai atau juga tertarik pada suatu hal dan aktivitas belajar tanpa ada yang menyuruh untuk belajar (Meilani, 2017) Minat belajar juga merupakan faktor pendorong untuk siswa dalam belajar yang didasari atas ketertarikan atau juga rasa senang keinginan siswa itu untuk belajar (Yunitasari and Hanifah, 2020). Tanpa adanya minat belajar dalam diri mahasiswa, maka akan mengakibatkan kurang optimalnya hasil dalam proses pembelajaran (Sutriyani, 2020).

Minat belajar yang tinggi akan membantu dalam pencapaian tujuan pembelajaran yang sebenarnya. (Yulyani, 2020) menyatakan Minat belajar adalah aspek psikologis dari peserta didik ditunjukan dengan gejala berikut:semangat, kemauan, gairah, dan rasa suka untuk melakukan perubahan diri dan sikap dari proses pencarian pengetahuan dan pengalaman dari pembelajaran.

Tingkat penularan Covid 19 yang masih tinggi memaksa kegiatan pembelajaran masih berlangsung secara daring, walaupun muncul berbagai keluhan dari berbagai pihak terutama mahasiswa. Mahasiswa sudah mulai menunjukkan kearah titik jenuh terhadap pembelajaran daring. Minat menjadi sumber motivasi yang kuat untuk belajar dan menjadi penyebab partisipasi dan keaktifan seseorang dalam kegiatan pembelajaran. Hal ini tercermin dari minat mahasiswa yang cenderung menurun untuk mengikuti perkuliahan daring. Minat yang menurun tersebut terlihat dari fakta yang penulis dapatkan dilapangan ditemui bahwa tingkat keikutsertaan mahasiswa dalam perkuliahan seperti sering absen dan terlambat mengikuti perkuliahan, bahkan tidak ikut sama sekali. Kurangnya partisipasi dan keterlibatan mahasiswa dalam perkuliahan daring terlihat dari tugas-tugas yang terlambat dikumpulkan dan kurangnya partisipasi dalam diskusi pada perkuliahan daring.

Berdasarkan survey yang dilakukan UNICEF menunjukkan bahwa sebanyak 66 persen dari 60 juta siswa dari berbagai jenjang pendidikan di 34 propinsi mengaku tidak nyaman belajar di rumah selama pandemi Covid-19 (Pininta, 2020). Bukan tanpa alasan bila siswa merasa tak nyaman saat harus belajar dari rumah ketimbang di sekolah. Berdasarkan hasil survey tersebut mengisyaratkan baha lebih dari separoh peserta didik sudah mulai merasakan ketidaknyamanan pembelajaran daring. Survei juga mendapati, selama belajar di rumah, 38 persen siswa yang jadi responden mengatakan kekurangan bimbingan dari guru menjadi kendala utama. Kekurangan bimbingan guru ini juga dapat menyebabkan kurangnya minat peserta didik untuk mengikuti pembelajaran secara daring.

Berbagai kelemahan pembelajaran daring seperti yang disampaikan bisa memberikan akibat atau dampak pada minat belajar mahasiswa terhadap mata kuliah yang diampu saat musim pandemi ini. Dimana minat ini juga bisa berakibat pada nilai yang akan diperoleh oleh mahasiswa. Belum lagi sistem ujian akhir semester melalui sistem daring dengan tingkat kerumitan yang tinggi serta waktu yang ditentukan sangat mempengaruhi minat dan nilai mahasiswa (Jamil and Aprilisanda, 2020).

Selain berbagai kelemahan yang disampaikan dalam pembelajaran daring juga menuai banyak kelebihan. Dari segi kelebihan pembelajaran daring memberikan fleksibilitas tempat dan waktu menciptakan suasana belajar baru menghemat uang transport, peserta didik dapat belajar sesuai dengan gaya belajar masing-masing, waktu berkumpul dengan keluarga lebih banyak, peserta didik lebih bertanggung jawab, kreatif, dan mandiri (Rahmawati, Rosida and Kholidin, 2020).

Bersumber pada permasalahan yang diungkapkan tersebut, maka peneliti terdorong untuk memberikan gambaran seberapa besar tingkat minat yang dimiliki mahasiswa dalam mengikuti perkuliahan daring masa pandemic covid-19. Dari hasil penelitian ini dapat memperkaya data tentang tingkat minat belajar mahasiswa dalam perkuliahan daring selama masa pandemic covid-19. Hal unik dari kajian ini yang belum banyak dikaji 
1641 Analisis Tingkat Minat mahasiswa Pendidikn Ekonomi dalam Perkuliahan Daring Masa Pandemi Covid-

19-Dessyta Gumanti, Serli Diovani Teza

DOI : https://doi.org/10.31004/edukatif.v3i4.623

pada beberapa penelitian sebelumnya adalah kajian tingkat persentase minat belajar mahasiswa dalam pembelajaran daring dengan menggunakan skala guttman karena peneliti ingin mendapatkan jawaban yang tegas (konsisten) terhadap suatu permasalahan yang ditanyakan. Hasil kajian ini diharapkan dapat menemukan upaya yang kontributif dalam upaya meningkatkan minat belajar mahasiswa dalam pembelajaran daring daring pada masa pandemic covid 19. Mahasiswa yang terbiasa tatap muka langsung belajar dikelas, tetapi karena adanya pandemic harus melakukan pembelajaran secara daring atau online yang tentunya mempengaruhi minat belajar mahasiswa.

\section{METODE PENELITIAN}

Penelitian ini menggunakan metode deskriptif kualitatif. Penelitian ini juga mengkaji bentuk, aktivitas, karakteristik, perubahwan, hubungan, kesamaan dan perbedaannya dengan fenomena lainnya. Dasar pemikiran digunakannya metode ini adalah karena penelitian ini ingin mengetahui tentang fenomena yang ada dan dalam kondisi yang alamiah, bukan dalam kondisi terkendali, labolatoris atau eksperimen. Di samping itu, karena peneliti perlu untuk langsung terjun ke lapangan bersama objek penelitian sehingga jenis penelitian kualitatif deskripstif kiranya lebih tepat untuk digunakan.

Subjek dalam mahasiswa semester 4 dan semester 6 Program Studi Pendidikan Ekonomi Universitas Ekasakti Padang dengan total jumlah mahasiswa 33 orang dengan rincian mahasiswa semester 4 sebanyak 15 orang dan mahasiswa semester 6 sebanyak 18 orang. Alat pengumpulan data yang digunakan yaitu angket. Angket yang digunakan adalah angket tertutup yang nantinya hasilya akan diolah secara deskriptif untuk menjabarkan hasil penelitian. Angket digunakan untuk melihat sejauhmana tingkat minat mahasiswa dalam pembelajaran online selama masa pandemi. Angket diberikan dengan menggunakan google form. Penulis menggunakan kuesioner dengan skala Guttman. Penelitian menggunakan skala guttman dilakukan bila ingin mendapatkan jawaban yang tegas (konsisten) terhadap suatu permasalahan yang ditanyakan.

Skala Guttman disebut juga skala scalogram yang sangat baik untuk meyakinkan hasil penelitian mengenai kesatuan dimensi dan sikap atau sifat yang diteliti. Menurut Usman dan Abdi (2011) bahwa "skala Guttman sangat baik untuk meyakinkan peneliti tentang kesatuan dimensi dan sikap atau sifat yang diteliti, yang sering disebut dengan atribut universal" Adapun skoring perhitungan responden dalam skala Guttman adalah sebagai berikut:

Table 1. Skoring Skala Guttman

\begin{tabular}{lccc}
\hline \multicolumn{1}{c}{ Alternatif Jawaban } & \multicolumn{3}{c}{ Skor Alternatif Jawaban } \\
& Positif & \multicolumn{2}{c}{ Negatif } \\
\hline Ya & & 1 & 0 \\
Tidak & 0 & 1 \\
\hline
\end{tabular}

Jawaban dari responden dapat dibuat skor tertinggi "satu" dan skor terendah "nol", untuk alternatif jawaban dalam kuesioner, penyusun menetapkan kategori untuk setiap pernyataan positif, yaitu Ya = 1 dan Tidak $=0$, sedangkan kategori untuk setiap pernyataan negatif, yaitu $\mathrm{Ya}=0$ dan Tidak $=1$. Maka peneliti menyebarkan angket yang harus dijawab dengan 20 item pertanyaan dari 4 buah indicator mengenai minat belajar yaitu perasaan senang, perhatian, ketertarikan dan keterlibatan dalam perkuliahan daring kepada 33 mahasiswa Pendidikan Ekonomi Universitas Ekasakti semester 4 dan semester 6 pada semester genap tahun akademik 2020/2021.

Analisis data merupakan kegiatan untuk meneliti, memeriksa, mempelajari, membandingkan data yang ada dan membuat interprestasi yang diperlukan. Analisis dilakukan untuk memperkirakan apakah semua aspek pembelajaran yang terlibat didalamnya sudah sesuai dengan kapasitasnya. Analisis yang dilakukan pada penelitian ini menggunakan data kuantitatif. Analisis dilakukan untuk melihat tingkat minat belajar mahasiswa dalam belajar daring selama masa pandemic. Untuk menghitung persentase digunakan rumus sebagai berikut: 
1642 Analisis Tingkat Minat mahasiswa Pendidikn Ekonomi dalam Perkuliahan Daring Masa Pandemi Covid19-Dessyta Gumanti, Serli Diovani Teza

DOI : https://doi.org/10.31004/edukatif.v3i4.623

Rumus Untuk Menghitung Presentase Minat :

$$
P=\frac{\mathrm{F}}{N} \times 100
$$

Keterangan :

$\mathrm{P} \quad=$ angka presentase

$\mathrm{F} \quad=$ jumlah jawaban responden

$\mathrm{N} \quad=$ Jumlah seluruh mahasiswa 33

Setelah presentasi diperoleh kemudian ditafsirkan dengan kalimat kualitatif dengan standar sebagai berikut :

$$
\begin{array}{ll}
76 \%-100 \% & =\text { Sangat Baik } \\
56 \%-75 \% & =\text { Cukup Baik } \\
40 \%-55 \% & =\text { Kurang Baik } \\
<40 \% & =\text { Tidak baik }
\end{array}
$$

\section{HASIL DAN PEMBAHASAN PENELITIAN}

Penelitian ini bertujuan untuk mengetahui gambaran tingkat minat belajar mahasiswa Pendidikan Ekonomi Universitas Ekasakti semester 4 dan semester 6 pada semester genap tahun akademik 2020/2021. Tingkat minat belajar mahasiswa tergambar berdasarkan pada jawaban mahasiswa terhadap angket yang diberikan dengan jumlah pernyataan sebanyak 20 buah pernyataan dan dengan menggunakan mahasiswa program studi Pendidikan Ekonomi semester 4 an 6 sebanyak 33 orang atau dengan teknik pengambilan sampel total sampling.

Minat belajar mahasiswa terhadap perkuliahan daring diukur menggunakan 4 indikator minat yaitu perasaan senang, perhatian, ketertarikan dan keterlibatan dalam perkuliahan daring. Keempat indicator tersebut digunakan untuk mengetahui sejauhmana minat mahasiswa dalam perkuliahan daring selama masa

\begin{tabular}{|c|c|c|c|c|c|c|c|}
\hline \multirow[t]{2}{*}{ No. } & \multirow[t]{2}{*}{ Indikator } & \multirow[t]{2}{*}{ Pernyataan } & \multicolumn{2}{|c|}{ Skor } & \multirow[t]{2}{*}{$\mathbf{F}$} & \multirow[t]{2}{*}{ Persentase } & \multirow[t]{2}{*}{ Kategor } \\
\hline & & & $\mathrm{Ya}$ & Tidak & & & \\
\hline \multirow[t]{6}{*}{1} & $\begin{array}{l}\text { Perasaan } \\
\text { senang }\end{array}$ & 1 & 10 & 23 & 10 & 30,3 & Tidak Baik \\
\hline & & 2 & 21 & 12 & 21 & 63,6 & Cukup Baik \\
\hline & & 3 & 20 & 13 & 20 & 60,6 & Cukup Baik \\
\hline & & 4 & 16 & 17 & 16 & 48,5 & Kurang Baik \\
\hline & & 5 & 20 & 13 & 20 & 60,6 & Cukup Baik \\
\hline & Rata-rata & & 17,4 & 15,6 & 17,4 & 52,7 & Kurang Baik \\
\hline \multirow[t]{6}{*}{2} & Perhatian & 6 & 14 & 19 & 14 & 42,4 & Kurang Baik \\
\hline & & 7 & 21 & 12 & 21 & 63,6 & Cukup Baik \\
\hline & & 8 & 22 & 11 & 22 & 66,7 & Cukup Baik \\
\hline & & 9 & 13 & 20 & 13 & 39,4 & Tidak Baik \\
\hline & & 10 & 24 & 9 & 24 & 72,7 & Cukup Baik \\
\hline & Rata-rata & & 18,8 & 14,2 & 18,8 & $\mathbf{5 7 , 0}$ & Cukup Baik \\
\hline 3 & Ketertarikan & 11 & 23 & 10 & 23 & 69,7 & Cukup Baik \\
\hline
\end{tabular}
pandemic ini.

Hasil penelitian tingkat minat belajar mahasiswa Pendidikan Ekonomi Universitas Ekasakti terhadap perkuliahan daring selama masa pandemic covid 19 tergambar pada table 2 .

Table 2. Hasil Rata-rata Skor Indikator Angket Minat Belajar Mahasiswa Pendidikan Ekonomi. 
1643 Analisis Tingkat Minat mahasiswa Pendidikn Ekonomi dalam Perkuliahan Daring Masa Pandemi Covid19- Dessyta Gumanti, Serli Diovani Teza : https://doi.org/10.31004/edukatif.v3i4.623

\begin{tabular}{|c|c|c|c|c|c|c|c|}
\hline \multirow[t]{2}{*}{ No. } & \multirow[t]{2}{*}{ Indikator } & \multirow{2}{*}{$\frac{\text { Pernyataan }}{12}$} & \multicolumn{2}{|c|}{ Skor } & \multirow{2}{*}{$\frac{\mathbf{F}}{25}$} & \multirow{2}{*}{$\begin{array}{c}\text { Persentase } \\
75,8\end{array}$} & \multirow{2}{*}{\begin{tabular}{l}
\multicolumn{2}{c}{ Kategori } \\
Cukup Baik
\end{tabular}} \\
\hline & & & 25 & 8 & & & \\
\hline & & 13 & 28 & 5 & 28 & 84,8 & Sangat Baik \\
\hline & & 14 & 27 & 6 & 27 & 81,8 & Sangat Baik \\
\hline & & 15 & 17 & 16 & 17 & 51,5 & Kurang Baik \\
\hline & Rata-rata & & 24 & 9 & 24 & 72,7 & Cukup Baik \\
\hline \multirow[t]{9}{*}{4} & Keterlibatan & 16 & 16 & 17 & 16 & 48,5 & Kurang Baik \\
\hline & & 17 & 21 & 12 & 21 & 63,6 & Cukup Baik \\
\hline & & 18 & 27 & 6 & 27 & 81,8 & Sangat Baik \\
\hline & & 19 & 26 & 7 & 26 & 78,8 & Sangat Baik \\
\hline & & 20 & 24 & 9 & 24 & 72,7 & Cukup Baik \\
\hline & Rata-rata & & 22,8 & 10,2 & 22,8 & 69,1 & Cukup Baik \\
\hline & \multicolumn{2}{|c|}{ Rata-rata } & 20,7 & 12,2 & 20,7 & 62,8 & Cukup Baik \\
\hline & \multirow{2}{*}{\multicolumn{2}{|c|}{$\begin{array}{l}\text { Skor tertinggi } \\
\text { Skor terendah }\end{array}$}} & 24 & 9 & 24 & 72,7 & Cukup Baik \\
\hline & & & 17,4 & 15,6 & 17,4 & 52,7 & Kurang Baik \\
\hline
\end{tabular}

Berdasarkan table diatas diketahui bahwa tingkat minat belajar mahasiswa Pendidikan Ekonomi Universitas Ekasakti dalam perkuliahan daring selama masa pandemic covid 19 berada pada posisi cukup baik. Hal ini terlihat dari $62,87 \%$ mahasiswa memiliki minat untuk mengikuti perkuliahan daring selama masa pandemic covid 19 dengan jumlah mahasiswa yang menjawab ya secara rata-rata sebanyak 20,75 dan yang menjawab tidak secara rata-rata sebanyak 12,25 dari total 33 responden. Sementara itu skor tertinggi terapat pada indicator perhatian mahasiswa dalam perkuliahan daring selama masa pandemi dengan persentase $62,87 \%$ yang menunjukkan bahwa mahasiswa memiliki perhatian yang cukup baik dalam mengikuti perkuliahan daring selama masa pandemic. Skor terendah terlihat pada indicator perasaan senang yang menunjukkan jumlah persentase sebesar 52,72 \% yang termasuk dalam kategori kurang baik yang bermakna bahwa mahasiswa kurang memiliki perasaan senang dalam mengikuti perkuliahan daring selama masa pandemic.

Hasil penelitian ini sejalan dengan hasil penelitian (Yunitasari and Hanifah, 2020) yang menyatakan pembelajaran daring berpengaruh terhadap minat belajar siswa. Sesuai pula dengan yang disampaikan oleh (Kurniawan and Makin, 2021) yang menyatakan pembelajaran daring dapat memberikan dampak yang positif terhadap minat belajar peserta didik. Hal ini bermakna bahwa semakin baik minat belajar yang dimiliki oleh mahasiswa akan menyukseskan pembelajaran daring yang dilaksanakan. Peningkatan minat belajar juga berkaitan dengan pembelajaran yang menarik. Pembelajaran yang menarik akan memompa semangat belajar sehingga memicu minat belajar yang semakin tinggi. Terkait dengan indicator perasaan senang yang memiliki rata-rata skor terendah dibandingkan dengan indicator lainnya, solusi yang dapat diberikan salah satunya adalah memberikan pembelajaran yang menarik agar mahasiswa senang dengan pembelajaran daring yang dilaksanakan. Pembelajaran yang menarik harus mampu diciptakan untuk menumbuhkan minat dan semangat belajar. Begitu juga pada perkuliahan, pembelajaran yang tidak monoton dan bervariasi tentu akan membuat peserta didik tertarik dan penasaran dengan apa yang akan mereka pelajari. Dibutuhkan juga semangat dan motivasi dari dosen atau guru sebagai pengelola kegiatan pembelajaran.

Selain itu, hasil penelitian ini juga sesuai dengan hasil penelitian (Sutriyani, 2020) yang menyimpulkan minat belajar mahasiswa pada mata kuliah pembelajaran matematika SD berbasis daring learning dengan menggunakan platform WA Group dan E learning termasuk dalam kategori setuju. (Sijabat, Sianipar and Siahaan, 2020) juga mengungkapkan hasil penelitiannya menyimpulkan bahwa pembelajaran berbasis daring berpengaruh terhadap minat belajar fisika umum mahasiswa Prodi Pendidikan Fisika Universitas HKBP 
1644 Analisis Tingkat Minat mahasiswa Pendidikn Ekonomi dalam Perkuliahan Daring Masa Pandemi Covid19-Dessyta Gumanti, Serli Diovani Teza

DOI : https://doi.org/10.31004/edukatif.v3i4.623

Nommensen Pematangsiantar. Daring Learning yang digunakan pada masa pandemi ini sebagai alternatif belajar mengajar di perguruan tinggi, karena dengan daring learning mahasiswa bisa berlatih umpan balik terkait menggabungkan kolaborasi kegiatan dengan belajar mandiri. Pembelajaran e-learning menuntut juga pembelajar untuk dapat belajar mandiri, oleh karena itu penting sekali menumbuhkan minat belajar agar tujuan pembelajaran dapat tercapai.

Indicator pertama yang digunakan untuk mengukur minat mahasiswa adalah mempunyai perasaan senang. Secara rata-rata diperoleh persentase $52,7 \%$ tergolong menunjukkan bahwa tingkat perasaan senang dalam minat belajar mahasiswa Pendidikan Ekonomi Universitas Ekasakti dalam perkuliahan daring selama masa pandemic covid 19 berada kedalam kategori kurang baik. Pernyataan yang memiliki jawaban paling rendah adalah pernyataan pertama yang mengungkapkan bahwa mahasiswa merasa tidak terpaksa mengikuti perkuliahan daring selama masa pandemic hanya sebesar 30,3\% sementara 69,3\% mahasiswa menyatakan mereka merasa terpaksa mengikuti perkuliahan daring selama masa pandemic. Sementara itu dalam indicator perasaan senang, mahasiswa tetap hadir tepat waktu dalam perkuliahan daring selama masa pandemi memiliki skor tertinggi dibandingkan dengan skor pernyataan lainnya dengan persentase 63,3\%. Kehadiran mahasiswa tepat waktu dalam perkuliahan cukup menunjukkan bahwa mahasiswa berminat mengikuti perkuliahan daring. Dalam hal ini siswa tidak begitu senang dengan diadakannya proses pembelajaran daring karena sudah merasa bosan dan jenuh setiap hari mengerjakan tugas di rumah dan tidak dapat bertemu dengan guru dan temanteman di sekolah untuk bermain, berdiskusi dan berinteraksi seperti mana biasanya (Santika, Sutisnawati and Uswantun, 2020). Proses pembelajaran yang berhasil seharusnya mampu untuk menciptakan suasana yang menyenangkan untuk kegiatan pembelajaran. Berbagai upaya dapat dilakukan agar mahasiswa merasa senang dengan kegiatan pembelajaran online adalah menggunakan berbagai platform e-learning yang menarik dan bervariasi sehingga mahasiswa merasa tertarik dan tertantang untuk belajar.

Indikator kedua yang digunakan untuk mengukur minat mahasiswa adalah perhatian yang diberikan mahasiswa dalam mengikuti perkuliahan daring terutama dalam masa pandemi secara rata-rata diperoleh skor sebanyak 18,8 dengan persentase 57\% yang bermakna bahwa perhatian mahasiswa Pendidikan Ekonomi Universitas Ekasakti dalam perkuliahan daring selama masa pandemic covid 19 tergolong cukup baik. Tingkat perhatian yang cukup baik ini terlihat pada skor jaaban tertinggi terdapat pada pernyataan mahasiswa mengerjakan setiap tugas yang diberikan dalam perkuliahan online dengan capaian skor sebanyak 24 dengan persentase $72,7 \%$ yang bermakna cukup baik. Sementara untuk capaian skor terendah dalam indicator perhatian adalah mahasiswa ketika tidak memahami materi mereka tidak diam saja dengan persentase 39,4\% yang bermakna kebanyakan mahasiswa hanya diam saja ketika mereka tidak paham dengan materi yang disampaikan dalam perkuliahan daring. Beralihnya pelaksanaan proses pembelajaran yang berawal dari konvensional atau tatap muka menjadi proses pembelajaran daring menyebabkan perhatian siswa terhadap pelaksanaan proses pembelajaran menjadi berubah (Santika, Sutisnawati and Uswantun, 2020).

Indicator ketiga yang digunakan untuk mengukur minat mahasiswa adalah ketertarikan dalam mengikuti perkuliahan daring secara rata-rata diperoleh skor 24 engan persentase $72,7 \%$ dengan kategori cukup baik. Tingkat ketertarikan yang cukup baik tergambar dalam capaian skor tertinggi dalam indicator ini yaitu mahasiswa akan mencari referensi di internet atau buku jika tiak memahami materi dengan skor 28 dan persentase $84,8 \%$ dengan kategori baik sekali. Hal ini menunjukkan bahwa mahasiswa mampu untuk mencari tambahan pengetahuan mengenai materi suah baik sekali ketika mereka tidak memahami materi secara langsung. Sedangkan capaian skor terendah terdapat pada pernyataan mahasiswa tidak akan menyalin tugas teman ketika kesulitan dalam mengerjakan tugas dengan perolehan skor sebanyak 17 dengan persentase $51,5 \%$. Hal ini menunjukkan bahwa lebih dari separoh mahasiswa akan menyalin tugas temannya ketika mereka kesulitan dalam menyelesaikan tugas-tugas yang dberikan secara online, terlebih lagi tugas-tugas dalam perkuliahan online biasanya menggunakan format pdf atau ord sehingga tingkat plagiarisme sangat tinggi. 
1645 Analisis Tingkat Minat mahasiswa Pendidikn Ekonomi dalam Perkuliahan Daring Masa Pandemi Covid-

19-Dessyta Gumanti, Serli Diovani Teza

DOI : https://doi.org/10.31004/edukatif.v3i4.623

Ketertarikan merupakan usaha atau daya dorong seseorang untuk menyukai pada sesuatu seperti hal nya menyukai pada materi maupun mata pelajaran tertentu. Faktor yang menjadi pendorong siswa dalam mengikuti proses pembelajaran daring adalah dengan adanya ketertarikan terhadap pembelajaran maka siswa akan antusias mengikuti proses pembelajaran dengan baik (Santika, Sutisnawati and Uswantun, 2020). Ketertarikan dalam mengikuti pembelajaran daring terlihat dari tingkat keingintahuan mahasiswa terhadap materi atau sering juga disebut kemandirian belajar. Kemandirian belajar bisa terlihat dari keinginan mahasiswa untuk mencari referensi lain selain dari materi yang diberikan oleh dosen untuk memperkaya pemahaman mereka mengenai materi yang dimaksud. Seperti yang diungkapkan (Harahap et al., 2021)Kemandirian dalam belajar perlu diberikan kepada siswa supaya mereka mempunyai tanggung jawab dalam mengatur dan mendisiplinkan dirinya dan dapat mengembangkan kemampuan belajar atas kemauan sendiri.

Indicator terakhir yang digunakan untuk mengukur minat mahasiswa dalam mengikuti perkuliahan daring dalam masa pandemic yaitu keterlibatan mahasiswa dalam perkuliahan diperoleh secara rata-rata dengan persentase $69,1 \%$ terkategori cukup baik keterlibatan mahasiswa. Tingkat keterlibatan mahasiswa terkategori baik sekali terdapat pada pernyataan dimana ketika diskusi berlangsung alam pembelajaran daring mahasiswa ikut berpartisipasi dengan memberikan pendapat dengan persentase $81,8 \%$. Sementara skor terendah terdapat pada pernyataan bahwa mahasiswa menyempatkan waktu belajar setiap hari dengan perolehan persentase $48,5 \%$ terkategori kurang baik.

Seperti yang disampaikan (Santika, Sutisnawati and Uswantun, 2020) Keterlibatan siswa pada saat pelaksanaan proses pembelajaran merupakan kunci utama dalam proses pendidikan karena sebagai faktor terpenting bagi keberhasilan proses pembelajaran dan akademik siswa. Tingkat aktivitas keterlibatan mahasiswa dalam proses pembelajaran daring akan membantu mahasiswa untuk mudah dalam memahami materi yang disampaikan. Edgar Dale mengemukakan tentang kerucut pengalaman (Cone of Experience) dimana partisipasi peserta didik dalam pembelajaran berupa keikutsertaan dan keterlibatan langsung dalam kegiatan, simulasi dan presentasi akan meningkatkan pemahaman materi 70-90\% (Huda, 2016). Dengan partisipasi yang tinggi dalam pembelajaran daring selama masa pandemic ini merupakan salah satu langkah agar dapat mempertahankan minat belajar mahasiswa yang terus menurun karena rasa bosan. Secara keseluruhan penelitian ini adalah untuk melihat tingkat minat belajar mahasiswa alaupun dengan kondisi pandemic. Hasil penelitian ini diharapkan dapat memberikan implikasi yang positif dalam upaya perbaikan dan peningkatan keberhasilan pembelajaran untuk mencapai tujuan pembelajaran yang diharapkan sehingga tercermin juga dalam kesuksesan hasil belajar mahasiswa.

\section{KESIMPULAN}

Berdasarkan hasil penelitian dan pembahasan dapat disimpulkan bahwa tingkat minat belajar mahasiswa Pendidikan Ekonomi Universitas Ekasakti dalam perkuliahan daring selama masa pandemic covid 19 terkategori cukup baik sebesar 62,87\% (56-75\%). Hal ini membuktikan bahwa mahasiswa tetap memiliki minat yang cukup baik dalam mengikuti perkuliahan daring, walaupun kegiatan pembelajaran berlangsung dengan situasi pandemic. Berdasarkan hasil penelitian di atas, saran yang penulis dapat sampaikan dan perlu diperhatikan yaitu pandemic covid-19 seharusnya bukanlah sesuatu yang membatasi mahasiswa untuk belajar, karena belajar bisa dimana saja dan dimana saja. Dengan meningkatkan partisipasi dalam perkuliahan, menimbulkan rasa senang dan ketertarikan dalam perkuliahan daring akan membantu mahasiswa untuk aktif dalam perkuliahan daring selama masa pandemic covid-19. 
1646 Analisis Tingkat Minat mahasiswa Pendidikn Ekonomi dalam Perkuliahan Daring Masa Pandemi Covid19- Dessyta Gumanti, Serli Diovani Teza

DOI : https://doi.org/10.31004/edukatif.v3i4.623

\section{DAFTAR PUSTAKA}

Akhirman, A. (2021) 'Pengaruh Aplikasi Zoom Kuliah Daring Terhadap Minat Belajar Mahasiswa Program Studi Manajemen Fakultas Ekonomi - UMRAH Pada Masa Pandemi Covid 19', Bahtera Inovasi, 3(2), pp. 103-109. doi: 10.31629/bi.v3i2.3327.

Argaheni, N. B. (2020) 'Sistematik Review: Dampak Perkuliahan Daring Saat Pandemi COVID-19 Terhadap Mahasiswa Indonesia', PLACENTUM: Jurnal Ilmiah Kesehatan dan Aplikasinya, 8(2), p. 99. doi: 10.20961/placentum.v8i2.43008.

Asrul and Afil, M. (2020) 'Dampak pembelajaran online terhadap minat belajar siswa pada masa pandemi covid-19', Publikasi Ilmiah Universitas Muhammadiyah Kendari, pp. 1-15.

Handayani, S., Annisya', A. and Andy, P. W. (2020) 'Peningkatan Kemandirian Belajar Mahasiswa di Masa Pandemi Covid-19 melalui Penerapan Blended learning pada Mata Kuliah Evaluasi Proses dan Hasil Belajar di Universitas Negeri Malang | Handayani | Jurnal Pendidikan Ekonomi’, Jpe, 13(2), pp. 152-164. Available at: https://dx.doi.org/10.17977/UM014v13i22020p152.

Harahap, H. S. et al. (2021) 'EDUKATIF : JURNAL ILMU PENDIDIKAN Hubungan Motivasi Berprestasi, Minat dan Perhatian Orang Tua Terhadap Kemandirian Siswa', 3(4), pp. 1133-1143.

HUDA, M. (2016) 'PEMBELAJARAN BERBASIS MULTIMEDIA DAN PEMBELAJARAN KONVENSIONAL (Studi Komparasi di MTs Al-Muttaqin Plemahan Kediri)', Jurnal Penelitian, 10(1), pp. 125-146. doi: 10.21043/jupe.v10i1.865.

Jamil, S. H. and Aprilisanda, I. D. (2020) 'Pengaruh Pembelajaran Daring Terhadap Minat Belajar Mahasiswa Pada Masa Pandemik Covid-19’, Behavioral Accounting Journal, 3(1), pp. 37-46. doi: 10.33005/baj.v3i1.57.

Kurniawan, D. E. and Makin (2021) 'Pengaruh Metode Pembelajaran Daring Terhadap Minat Belajar Mahasiswa Di Masa Pandemi Covid-19', Jurnal Education and Development, 9(2), pp. 47-51.

Meilani, R. I. (2017) 'Impak minat dan motivasi belajar terhadap hasil belajar siswa ( The impacts of students ' learning interest and motivation on their learning outcomes )', 2(2), pp. 188-201.

Pininta, A. K. (2020) 'Survei UNICEF: 66 Persen Siswa Mengaku Tak Nyaman Belajar di Rumah', Kompas.com, p. 1. Available at: https://edukasi.kompas.com/.

Rahmawati, N. R., Rosida, F. E. and Kholidin, F. I. (2020) 'Analisis Pembelajaran Daring Saat Pandemi Di Madrasah Ibtidaiyah', SITTAH: Journal of Primary Education, 1(2), pp. 139-148. doi: 10.30762/sittah.v1i2.2487.

Rani Dewi Yulyani (2020) 'Pengaruh Media Pembelajaran Google Classroom, Fasilitas Pembelajaran Dan Minat Belajar Mahasiswa Terhadap Motivasi Belajar Daring Selama Pandemi Covid-19', EdHumanistics : Jurnal Ilmu Pendidikan, 5(2), pp. 703-714. doi: 10.33752/ed-humanistics.v5i2.1071.

Santika, D., Sutisnawati, A. and Uswantun, D. A. (2020) 'DIKDAS MATAPPA : Jurnal Ilmu Pendidikan Dasar Analisis Minat Belajar Matematika Berbasis Daring', Jurnal Ilmu Pendidikan Dasar, 3(2), p. 30.

Sijabat, A., Sianipar, H. F. and Siahaan, T. M. (2020) 'Pengaruh Pembelajaran Daring Terhadap Minat Belajar Mahasiswa Pendidikan Fisika Uhkbpnp Pada Matakuliah Fisika Umum', The 2st National Conference on Education, Social Science, and Humaniora "Potensi Penelitian dan Pengabdian di Era New Normal" Mataram, 29 Desember 2020 LITPAM, Indonesia, pp. 84-88.

Sutriyani, W. (2020) 'Studi Pengaruh Daring Learning Terhadap Minat Dan Hasil Belajar Matematika Mahasiswa PGSD Era PAndemi Covid-19', Jurnal Pendidikan Dasar: Jurnal Tunas Nusantara, 2(1), pp. 155-165.

Yunitasari, R. and Hanifah, U. (2020) 'Pengaruh Pembelajaran Daring terhadap Minat Belajar Siswa pada Masa COVID 19', Edukatif: Jurnal Ilmu Pendidikan, 2(3), pp. 232-243. doi: 10.31004/edukatif.v2i3.142. 
1647 Analisis Tingkat Minat mahasiswa Pendidikn Ekonomi dalam Perkuliahan Daring Masa Pandemi Covid19- Dessyta Gumanti, Serli Diovani Teza

DOI : https://doi.org/10.31004/edukatif.v3i4.623 